\title{
A Felvidék magyarlakta területén múködő turisztikai szervezeti rendszer vizsgálata
}

\author{
Szerző: Tőzsér Anett ${ }^{1}$ - Bánhidai Csilla² - Fogarasi Noémi Blanka - Csonka Ákos ${ }^{4}$
}

A Kárpát-medence magyarlakta térségei megannyi ismert vagy kevésbé ismert vonzerôvel rendelkezô turisztikai fogadóterületek, amelyek versenyképességét meghatározza a turizmus szereplőinek együttmüködése is. Ezért a Nemzetstratégiai Kutatóintézet egy kutatássorozatot indított el, hogy ezen szervezetek múködéséról egy átfogó képet adjon. Ennek elsó, pilot projektjét a 2015 második felében elvégzett 'Székelyföld turisztikai szervezeti rendszerének vizsgálata' címú kutatás jelentette. Az ott kialakított módszertani gyakorlat alapján a kutatás helyszine 2017-ben a Felvidék magyarlakta területe. A kutatás várható eredménye, illetve az ez alapján megfogalmazott ajánlások a következó években hozzájárulhatnak ahhoz, hogy a Felvidék magyarlakta vidékein a turizmus a szervezeti háttér fejlesztésének köszönhetöen versenyképesebbé váljon, ezáltal újabb gazdasági lehetôségeket kínáljon a helyi magyar közösségek számára, elősegítve a szülőföldön történó megmaradásukat, társadalmi-gazdasági megerósödésüket. A kutatás eredményeivel a Felvidék magyarlakta területén, majd pedig a Kárpát-medencében készítjük eló és erôsítjük a turisztikai együttmúködéseket.

Kulcsszavak: Felvidék magyarlakta területe, TDM szervezet, turisztikai egyesület, turisztikai együttmúködés.

\section{A kutatás problémafelvetése, célja és módszere}

A Felvidék magyarlakta területe olyan sajátos térsége Szlovákiának és a Kárpát-medencének, amelynek jellegzetességét a magyarsághoz való tartozása, szerves kötődése adja meg.

A 2014-ben készült Baross-terv megállapításai szerint Szlovákia nem hasznosítja jól turisztikai adottságait, lehetőségeit. A dél-szlovákiai turizmus legfőbb problémái között említhető, hogy a kínálat összehangolása nem megfelelően szervezett, némely kínálati elem elérhetősége nehézkes, a turisztikai marketing, illetve a desztináció menedzsment tevékenység jelenleg még alacsony színvonalú (BAROSS GÁBOR TERV 2014). Ellentétben azonban például a magyarországi helyzettel, a TURIZMUS TÁMOGATASÁRÓL SZÓLÓ SZLOVÁK TÖRVÉNY (2010) egy világos és meghatározott jogszabályi keretet, valamint pénzügyi erőforráso-

\footnotetext{
osztályvezető és kutatásvezető, Nemzetstratégiai Kutatóintézet, anett.tozser@nski.gov.hu

${ }^{2}$ stratégiai tervező, Nemzetstratégiai Kutatóintézet, csilla.banhidai@nski.gov.hu

${ }^{3}$ stratégiai referens, Nemzetstratégiai Kutatóintézet, blanka.noemi.fogarasi@nski.gov.hu

${ }^{4}$ felvidéki referens, Nemzetstratégiai Kutatóintézet, akos.csonka@nski.gov.hu
}

kat biztosít a turisztikai szervezetek TDM típusú múködéséhez és a megfelelő kompetenciák kialakításához.

A turizmus teljesítményének viszonylagos elmaradása ellenére a Felvidék magyarlakta területeinek magyar közössége olyan belső tartalékokat hordoz, amelyek alapján kialakítható az alulról építkező, a sajátos és speciális gazdasági, illetve kulturális szempontokat szolgáló turizmuspolitika. A helyi szakértők úgy vélik, hogy az elmúlt évtizedek turisztikai fejlődése után megérett a térségben a Felvidék, mint sajátos és egyedi turisztikai fogadóterület szükségességének felismerése. Az indokok közé tartozhat a külsó és a belső imázs és identitás erősítésének szándéka, valamint a már megtett kezdeti lépések a térségi szervezeti rendszerek kialakítására. Ehhez a térség szereplőinek ki kell dolgozniuk a térségi összegfogáshoz (a TDM rendszer) szükséges alapokat.

A fenti problémafelvetésre építve, a kutatás célja objektív szempontok alapján megvizsgálni, hogy jelenleg milyen magyar TDM jellegú szervezetek vannak és múködnek a Felvidék magyarlakta területein; megvizsgálni a szervezeti múködés feltételeit, jogi és szakmai környezetét, a múködést segító és gátló tényezőket, a legsikeresebb kezdeményezéseket, illetve feltárni a sikeres múködés feltételeit, és mindezek alapján javaslatot tenni a turisztikai együttmúködések további lehetôségeire, formáira, múködésére.

A kutatás kvalitatív módszerrel készült. A hat kérdésblokkból, összesen negyven kérdéskörből 
álló, egyenként 1,5-2 órás szakmai interjú lehetőséget biztosított a téma mélységi vizsgálatára, a látens jelenségek feltárására. Ezzel a módszerrel lehetőség nyílt a felvidéki magyar szervezetek és szakemberek gondolkodásmódjának, cselekedeteinek és attitúdjének mélyebb megértésére. A térségben körülbelül 37 szervezet végez turisztikai tevékenységet, és ezen szervezetek turizmusra gyakorolt tényleges hatását figyelembe véve összesen 15 szervezet múködését és szakmai tevékenységét vizsgáltuk. A szervezeteket három csoportba soroltuk: TDM szervezetek; önkormányzati hátterû szervezetek (önkormányzati társulás, fejlesztési ügynökség, a települési önkormányzat egy osztálya, európai területi együttmúködési csoportosulás, fejlesztési társulás); valamint támogató jellegú szervezetek (civil szervezetek, szakmai szövetségek, érdekképviseleti szervezetek, valamint turisztikai egyesületek). Az elsó csoportban két, a második csoportban nyolc, a harmadik csoportban öt szervezetet vizsgáltunk. Az interjúk elkészítése 2017. június és szeptember között történt, az értékelés 2017 novemberében zárult.

A kutatás vizsgálati alapfogalmaként meghatározott TDM szervezet alatt a desztinációt alkotó szereplők (önkormányzat, vállalkozások, szakmai és civil szervezetek) szervezett együttmúködésén alapuló olyan önkéntes tevékenységet értjük, amelynek célja a turistáknak élmény, a fogadó közösség számára pedig gazdasági, társadalmi és környezeti előnyök nyújtása; a turisztikai kínálat koordinálása, a közös tervezés- és marketingtevékenység (LENGYEL 2008, BUHALIS 2000). Küldetése a fenntartható és versenyképes turizmus rendszer kialakítása és múködtetése egy turistákat fogadó térségben (NEMZETI TURIZMUSFEJLESZTÉSI STRATÉGIA 2005, LENGYEL 2008).

Az elmúlt években a magyar külhoni desztinációkban létrejött TDM szervezetek már lehetőséget teremtenek tevékenységük értékelésére: menynyire hatékonyan képesek ellátni tevékenységüket (szervezeti felépítés, turisztikai szereplők összefogása, termékfejlesztés, marketingkommunikációs tevékenység, finanszírozás), és hogyan tudnak hozzájárulni az illetékességükbe tartozó földrajzi terület versenyképességéhez és gazdasági fenntarthatóságához.

E szempontokat figyelembe véve, kutatásunkban a TDM szervezetek tevékenységét hat kérdéskörben vizsgáltuk:

- múködési modell (szervezeti felépítés),

- finanszírozás (forrásbevonás),

- együttmúködések (tagsággal és más szervezetekkel),

- turisztikai termékfejlesztés,

- marketingkommunikációs tevékenység,
- a szervezetek és a Felvidék magyarlakta területének turisztikai versenyképessége.

\section{Rövid turisztikai helyzetértékelés}

A kutatás vizsgálati hatóköre a Felvidék magyarlakta területe, azaz Dél-Szlovákia. Ebben az értelmezésben a felvidéki táj nem egy földrajzi egység, hanem egy kelet-nyugati irányban hosszan elnyúló terület, amely a történelmi Magyarország részeként és földrajzilag is inkább kapcsolódik a magyarországi tájegységhez, mint a mesterséges határ által Szlovákiához kapcsolt területekhez. Jelenleg a Szlovákiában élő magyarság ezen a körülbelül 500 kilométer hosszan elnyúló kelet-nyugati területen él ${ }^{5}$. Közigazgatási szempontból a Felvidék magyarlakta területei öt kerületet érintenek: Kassa, Besztercebánya, Pozsony, Nagyszombat és Nyitra. A többségében szlovákok lakta kerületek: Eperjes, Trencsén, Zsolna (CSONKA 2014, FELVIDEKI MAGYAROK 2012, HORVÁTH 2004, SZLOVÁK STATISZTIKAI HIVATAL).

A Felvidék magyarlakta területe gazdag természeti kincsekben, egy részük megtalálható az UNESCO jegyzékén is. A természeti vonzerők közül kiemelkednek a természet aktív felfedezését és a pihenést biztosító nemzeti parkok (például a Szlovák-karszt és a Murányi-fennsík Nemzeti Park), a barlangok (például a Dobsinaijégbarlang, a Gombaszögi-barlang, a Jászóibarlang és a Martonházi-aragonitbarlang), valamint a gyógy- és termálfürdők (komáromi és pati gyógyfürdő, dunaszerdahelyi, érsekújvári, párkányi, nagymegyeri-, alsósztregovai-, rappi Novolandia és galántai termálfürdô) (CSIFFÁRY 2007, NAGY 2015).

A kulturális és a történelmi emlékek a turizmus meghatározó kínálati elemét jelentik (VIDA 2016, CSIFFÁRY 2007, GÁSPÁR et al. 2005, SZOBONYA 2014, KÓSA 2014). Szlovákia körülbelül 12 ezer múemléki jegyzékbe felvett épülettel, értékkel rendelkezik, ezeknek ugyanakkor csak a töredékét használják turisztikai célokra (HORVÁTH 2004). A Felvidéken közel 700 kastély található, melyek egy része eredeti állapotban maradt meg és felújították, a többi kastélyrom. A térség leglátogatottabb kastélya a betléri kastély. A várak között Pozsony és Komárom vára jelenik meg elsődleges vonzótényezőként, ezen kívül másodlagos vonzótényezőként említhető Kékkő, Fülek, Somoskő, Léva, Nyitra vára. A térségben a magyar történelem emlékeit hordozzák a városok, mint például Pozsony, Kassa, Komárom (VIDA 2016, CSIFFÁRY 2007, GÁSPÁR et al. 2014).

5 http://www.magyarokatlasza.hu/felvidek.html 
Szlovákiában 2015-ben 198858 szállásférőhely állt rendelkezésre. A vendégfogadási feltételek 2001 és 2015 közötti időszakának vizsgálata alapján megállapítható, hogy 2001 és 2015 között a szálláshelyek kapacitása kisebb mértékben növekedett (15\%), mint a szálláshelyek száma (64\%). A szálláshely-kapacitások növekedése a magyarlakta térségekben 16-86 százalék között változik, és nem éri el a szálláshelyek számának növekedését. A magyarlakta térségek mind a szálláshelyek száma, mind a szálláshely-kapacitások tekintetében a középmezőnyben helyezkednek el a szlovák kerületekhez képest (SZLOVÁK STATISZTIKAI HIVATAL). A szálláshelyek száma és a szálláshely-kapacitások száma tekintetében a térségek sorrendje az alábbi (kiemelve a zömében magyarlakta kerületeket) (1. táblázat).

\section{Szlovák kerületek sorrendje \\ 1. táblázat a szálláshelyek száma és a szállásféróhelyek száma tekintetében}

\begin{tabular}{|l|c|l|c|}
\hline \multicolumn{2}{|c|}{$\begin{array}{c}\text { Szálláshelyek száma } \\
(\text { db/2015) }\end{array}$} & \multicolumn{1}{c|}{$\begin{array}{c}\text { Szállásféröhelyek száma } \\
\text { (db/2015) }\end{array}$} \\
\hline 1. Zsolnai kerület & 970 & 1. Zsolnai kerület & 40360 \\
\hline 2. Eperjesi kerület & 718 & 2. Eperjesi kerület & 33927 \\
\hline 3. Besztercebányai kerület & 550 & 3. Pozsonyi kerület & 28135 \\
\hline 4. Kassai kerïlet & 351 & 4. Besztercebányai kerület & 22206 \\
\hline 5. Nyitrai kerület & 312 & 5. Kassai kerület & 25989 \\
\hline 6. Nagyszombati kerület & 293 & 6. Nyitrai kerület & 16882 \\
\hline 7. Trencséni kerület & 288 & 7. Nagyszombati kerület & 16378 \\
\hline 8. Pozsonyi kerület & 242 & 8. Trencséni kerïlet & 14981 \\
\hline Szlovákia összesen & 3724 & Szlovákia összesen & 198858 \\
\hline
\end{tabular}

Forrás: Szlovák Statisztikai Hivatal

Szlovákia 2015-ben 4,3 millió vendéget fogadott, és a 2001-2015 közötti 15 év alatt a vendégszámok 37 százalékos növekedést jeleznek. A magyarlakta térségek esetében is eltérô mértékú, de folyamatos növekedés tapasztalható (6-98\%). Az elsődleges motiváció, amely miatt a látogatók a Felvidék magyarlakta területeire utaznak, a városlátogatás, a történelmi várak és kastélyok meglátogatása, a természeti kincsek megtekintése, a kirándulás és a történelmi emlékhelyek meglátogatása (SZLOVÁK STATISZTIKAI HIVATAL).

A külföldi turisták kedvenc célpontja Pozsony, ahol tízből négy turista fordul meg, ezt követi Zsolna és Eperjes, amelyek a hegyeikkel vonzzák a látogatókat. A szlovák belföldi turistáknak csak 16 százaléka választotta Pozsonyt, ebben a szegmensben
Zsolna (22\%) és Eperjes (18\%) dominál. A vendégek és a vendégéjszakák száma tekintetében a magyarlakta kerületek Szlovákia vendégforgalmában a középső és az utolsó mezőnyben helyezkednek el Pozsony kivételével, amely vezetô szerepet tölt be a magyarlakta területek (és Szlovákia) vendégforgalmában (SZLOVÁK STATISZTIKAI HIVATAL). A vendégek számának és a vendégéjszakák számának tekintetében a térségek sorrendje az alábbi (kiemelve a zömében magyarlakta kerületeket) (2. táblázat).

\section{2. táblázat}

Szlovák kerületek sorrendje a vendégek száma és a vendégéjszakák száma tekintetében

\begin{tabular}{|l|c|l|c|}
\hline \multicolumn{2}{|c|}{ Vendégek száma (fö/2015) } & \multicolumn{2}{c|}{$\begin{array}{c}\text { Vendégéjszakák száma } \\
\text { éjszaka/2015) }\end{array}$} \\
\hline 1. Pozsonyi kerület & 1194479 & 1. Pozsonyi kerület & 2554879 \\
\hline 2. Zsolnai kerület & 846508 & 2. Zsolnai kerület & 2440296 \\
\hline 3. Eperjesi kerület & 740701 & 3. Eperjesi kerület & 2362386 \\
\hline $\begin{array}{l}\text { 4. Besztercebányai } \\
\text { kerület }\end{array}$ & 448568 & $\begin{array}{l}\text { 4. Besztercebányai } \\
\text { kerület }\end{array}$ & 1397260 \\
\hline $\begin{array}{l}\text { 5. Nagyszombati } \\
\text { kerület }\end{array}$ & 297693 & $\begin{array}{l}\text { 5. Nagyszombati } \\
\text { kerület }\end{array}$ & 1181037 \\
\hline 6. Trencséni kerület & 274360 & 6. Trencséni kerület & 1108518 \\
\hline $\begin{array}{l}\text { 7. Kassai kerület } \\
\text { 8. Nyitrai kerület }\end{array}$ & 266358 & 7. Nyitrai kerület & 707945 \\
\hline Szlovákia összesen & 4330249 & 8. Kassai kerület & 597759 \\
\hline
\end{tabular}

Forrás: Szlovák Statisztikai Hivatal

\section{A Felvidék magyarlakta területén múködó szervezetek turisztikai tevékenységének bemutatása - a primer kutatás eredményei}

A következőkben a szervezetek múködésének jellemzőit foglaljuk össze.

\subsection{SZERVEZETI MODELL}

A Felvidék magyarlakta területén két magyar térségi szintû TDM szervezet múködik: a Csallóköz Területi Idegenforgalmi Szövetség és a Dunamente TDM szervezet. A döntéseket minden esetben a közgyúlés hozza, amely megválasztja az igazgatótanácsot, amelynek élén az elnök áll. A TDM szervezetek közül a Dunamente TDM szervezet rendelkezik munkaszervezettel, amelynek vezetője az ügyvezető igazgató. A Csallóköz Területi Idegenforgalmi Szövetségnek még nincsen munkaszervezete, itt az operatív feladatokat az elnök és a tagság 
végzi. Mindkét szervezetben aktív a tagság részvétele a közgyúlésen, ugyanakkor a szakmai munkában közepes mértékú aktivitás jellemző. Szakmai tevékenységük a tervezés szakaszában, marketing tevékenységük a megvalósítás kezdeti szakaszában tart, ugyanakkor már láthatóak a fejlődés jelei. A szervezetek törekszenek a térségi összefogásra.

$\mathrm{Az}$ önkormányzati hátterú szervezetek önkormányzatok együttmúködésére épülnek, tagjaik vagy kizárólag önkormányzatok, vagy önkormányzatok és vállalkozások. A tagság aktivitása, részvétele a programokban, közös feladatokban változó. A szakmai tevékenységeket ellátó munkaszervezet aktív, a tagság azonban kevéssé, vagy közepes mértékben kapcsolódik be a szakmai tevékenységekbe. Jelentôs térségszervező erővel rendelkeznek, azonban nem kizárólag turisztikai tevékenységet látnak el.

A támogató jellegú szervezetek turisztikai és kulturális tevékenységükkel támogatják a Felvidék magyarlakta területe turizmusának fejlódését. A szervezetek tagjai sorában vagy önkormányzatok és vállalkozások, vagy magánszemélyek, vagy vállalkozások vannak. Az operatív feladatokat több szervezetben a vezetőség, vagy a munkaszervezet és az annak élén álló igazgató, illetve egy esetben a tagság végzi. Egy szervezet rendelkezik nagyobb munkatársi létszámmal, a többi esetben önkéntesek, vagy az elnökség és a tagság látják el a feladatokat. A szakmai tevékenységek egy részében a tagok aktívak (szervezetek által szervezett programokon való részvétel, a tevékenységek során a saját tehetség és tudás hozzáadása), azonban öszszességében közepesen aktívak a programcsomagok kialakításában, a kommunikációs kampányokon való részvételben. Két szervezet tevékenysége a teljes Felvidék területére kiterjed, míg másoké egy-egy településre, térségre, illetve egy esetben Pozsonyra.

\subsection{SZERVEZETEK FINANSZÍROZÁSA}

A TDM szervezetek számára a tagdíjak és a hozzá kapcsolódó állami dotáció, valamint a pályázati források jelentik a legfőbb bevételi tételt, amit kis részben a kereskedelmi célú bevételek egészítenek ki. A két TDM szervezetet vizsgálva látható, hogy a Dunamente TDM szervezet tervezi bevételt hozó tevékenységek bevezetését, míg a Csallóköz Területi Idegenforgalmi Szövetség egyelőre nem tervezi a saját bevételt hozó tevékenységek bevezetését, stabilnak tartja gazdálkodását. A törvényi háttér és az ennek köszönhetó állami dotáció stabil múködési feltételeket biztosít a TDM szervezetek számára, azonban ha valamely erősebb szereplő kilépne a szervezetekból, abban az esetben a finanszírozás átstrukturálást igényelne, mert a vendégéjszakák száma és ezáltal a tagdíjak csökkenése befolyásolja az állami támogatás mértékét. A tagdíjak alapját az idegenforgalmi adó, illetve a lakosságszám, valamint a vállalkozói bevételek jelentik.

A szlovákiai székhelyú önkormányzati hátterú szervezetek számára a szlovák állami normatív, múködési célú források, a magyarországi székhelyú önkormányzati hátterú szervezetek számára pedig a magyarországi állami normatív, múködési célú források állnak rendelkezésre. A második legnagyobb tételt az európai uniós és az állami pályázatok jelentik, majd ezt követik a tagdíjbevételek. A saját üzleti célú bevételek és a szponzori támogatások még viszonylag kevés bevételi forrást jelentenek. Az önkormányzati háttér a többség esetében ugyan stabilabb finanszírozást tesz lehetôvé, azonban vannak szervezetek, amelyeknek nehézséget okoz a múködés, és van olyan szervezet is, amely közel áll a megszúnéshez. A gazdasági fenntarthatóság tehát az ő esetükben kevéssé megalapozott, mint a TDM szervezetek esetében.

A támogató szervezetek bevételei fóként az állami típusú pályázatokból, részben szponzori támogatásokból, ezen kívül tagdíjakból és saját üzleti célú forrásokból származnak. Szinte valamennyi szervezet jelezte, hogy pénzügyi szempontból nem, vagy csak nehezen fenntartható a tevékenysége, mert nem állnak rendelkezésre múködési célú források, illetve csak kis mértékben végeznek saját bevételt eredményezô tevékenységeket.

\subsection{TURISZTIKAI TERMÉKFEJLESZTÉS}

A válaszadók véleménye összhangban van a keresleti és kínálati statisztikai adatokkal, melyek szerint Szlovákia elsôdleges vonzerejét a természeti adottságok jelentik, így a hegyek, a barlangok és a vizek. Konkrét vonzeróket említve a Magas- és Alacsony-Tátra, a Szlovák Paradicsom, a Dobsinai-jégbarlang, a gyógy- és termálfürdők (Párkány, Pöstyén, Poprád, Gyúgy stb.), másrészt a vízi turizmus lehetóségei (Duna, Ipoly, Garam folyók térsége, Bodrogköz) emelhetők ki.

A válaszadók véleménye szerint Szlovákia másodlagos turisztikai vonzerejét a kulturális vonzerók jelentik. Ezen belül kiemelhetők a történelmi városok, a várak és kastélyok, így például a legtöbbet említett Krasznahorka vára, a betléri Andrássy-kastély, a bajmóci, a füleki, a kékkői, a szepesi, a trencsényi, és a vöröskôi várak, amelyek főként a dél-szlovákiai térségben találhatók és nagyobb részük magyar vonatkozású érték. A kulturális értékek között kiemelt szerepet kapnak a városok is, amelyek közül Pozsony, mint a történelmi Magyarország egykori fôvárosa, valamint Kassa, Komá- 
rom és Rozsnyó kapott több említést. Ezen kívül a bányavárosokat emelték még ki, illetve sokan öszszefoglalóan utaltak a magyar történelmi városok kiemelkedő turisztikai szerepére.

A válaszadók másik része nem feltétlenül vonzerőket, hanem turisztikai térségeket azonositott, amelyek a turizmus piacán egységes termékcsomagként jól értékesíthetőek, mint például Gömör, Csallóköz, vagy a Duna mente. A válaszadók harmadik csoportja turisztikai termékcsoportokat emelt ki, melyek közül főként a bor- és a gasztronómiai turizmus jelenti Szlovákia vonzerejét, a vallási turizmus ugyanakkor alig jelent meg a válaszokban.

A Felvidék magyarlakta területének vonzerői között elsô helyen állnak a kulturális vonzerôk, melyen belül kiemelhetók a várak és kastélyok (többek között a komáromi erődrendszer, a füleki, a somoskői, az ajnácskői vár, a betléri kastély, Krasznahorka vára, a kékkői vár, a szepesi vár és Perbenyikben a Mailáth-kastély). A városok között első helyen szerepel Pozsony, amit Komárom és Párkány követ, majd Dunaszerdahely, Rozsnyó és Mucsény. Ezen kívül a kiemelkedő munkásságú magyarok emlékhelyei is sok említést kaptak, így különösen Kossuth Lajos, Madách Imre, Mikszáth Kálmán, Tompa Mihály emlékhelyei.

A borturizmus és a borutak a válaszadók több mint fele számára jelentenek vonzerôt. A természeti adottságok között a víz szerepe jelent meg kiemelten, főként a termál- és gyógyfürdők (Párkány, Pat, Nagymegyer), de a dunai vízi turizmus, valamint az ehhez szorosan kapcsolódó kerékpáros turizmus is több említést kapott. Látható tehát, hogy a magyarlakta területen a turisztikai vonzerók azonosítása a legtöbb esetben egybeesik a magyarság kiemelkedó értékeivel.

A szervezetek a jövőben a térség ismertségének növelését, identitásának, márkájának építését jelölték meg fejlesztendő célként, mert a többség válaszai szerint rendelkeznek vonzerókkel, de a látogatók kevéssé ismerik ezeket. A vonzerófejlesztésen belül a Duna szerepét fontos kiemelni: a kikötőépítés, a vízi turizmus szolgáltatási hátterének, és ehhez kapcsolódóan a kerékpáros turizmusnak a fejlesztése jelent meg igényként. A rendezvények számának bóvítése és színvonaluk növelése mellett kiemelték a magyar identitásépítést szolgáló rendezvények szervezését, valamint a gasztronómiára és a sportra építő rendezvényeket. A fejlesztési igények sorában megjelent még a helyi termékek értékesítésének és az információ közvetítésnek is lehetőséget biztosító látogató-, és/vagy információs központok kialakítása. A vonzerőfejlesztés célját nem lehet külön választani az átlagos tartózkodási idő bővítésétől sem.

\subsection{SZERVEZETEK MARKETINGKOMMUNIKÁCIÓJA}

A Felvidék magyarlakta területén sokkal jobb online jelenléttel és elérhetőséggel találkoztunk, mint az erdélyi vizsgálatunk során, ugyanakkor még így is elmondható, hogy a vizsgált szervezetek egy részét nem könnyen tudtuk azonosítani és elérni. Ezen kívül a többnyelvûség terén is érdemes fejlődni, hogy az információk nagyobb célközönséghez jussanak el.

A TDM szervezetek törekszenek a többnyelvú kommunikációra, ami látható a honlapjuk kialakításánál. Más honlapokon és a közösségi médiában is hirdetik programjaikat, amelynek nagy reklámértéket tulajdonítanak. Ezen kívül több ezres példányszámban tematikus kiadványokat készítenek, többnyelvú mutációban. Jellemzó még a turisztikai kiállításokon való megjelenés, ugyanakkor más marketingkommunikációs eszközt nem alkalmaznak. Eladásösztönző eszköz bevezetését a jövőben tervezik. Még nem végeznek belső és külső PR tevékenységet, és nincs megjelenésük a TVben, vagy a rádióban.

Az önkormányzati hátterú szervezetek általában rendelkeznek honlappal, a nyolc szervezetból két szervezet tervezi annak kialakítását, a többi szervezet részben egynyelvú, részben többnyelvú modern, korszerú weblappal rendelkezik. A legtöbben aktívan megjelennek a közösségi média felületein és más honlapokon is. Két szervezet kivételével minden szervezetnek van kiadványa, de ezek sikerességét a célközönség eléréséhez változónak ítélték meg. Szakmai kiállításokon két szervezet vesz részt, melynek hatékonyságát közepesnek ítélik. A médiában rádió- és TV beszélgetések formájában vannak jelen, amelyek során rendezvényeikről és a projektek megvalósításáról adnak hírt. Többen említették az M1 csatornát, a rádiós megjelenésnél a Pátria rádiót. Eladásösztönzó eszközt egy szervezet alkalmaz, a Dunakanyar kártya formájában, melyen kívül külső és belső PR eszközként említették még a szervezet által tagjaik, külső partnereik és az érdeklődők számára megvalósított rendezvényeket, fesztiválokat.

A támogató szervezetek minden online lehetóséget kihasználnak, van saját honlapjuk, amely magyarul és szlovákul érhető el. Kiemelendő a Szlovákiai Magyar Múvelődési Intézet egyedülálló online adattára a felvidéki értékekról, illetve a Pozsonyi Kifli Társulás honlapja, amely Szlovákia leglátogatottabb történeti honlapja. A szervezetek jelen vannak más honlapokon és közösségi oldalakon is, ezen kívül egy kivételével minden szervezet rendelkezik kiadványokkal, amelyeket anyagi lehetőségeikhez mérten pár százas, vagy ezres 
példányszámban jelentetnek meg. Egy szervezet jelenik meg turisztikai kiállításokon, a többi rendszerint települési/térségi kiállításokon vesz részt. Rendezvények alkalmával rendszeresen megjelennek a TV-ben és rádióban (M1-en, Duna TV-ben, Pátria rádióban, Kossuth rádióban). Eladásösztönző eszközöket az öt szervezetból három használ: olyan kártyákat, amelyek kedvezményes részvételi lehetőséget biztosítanak a tagságnak, illetve a helyi lakosoknak. DM hírlevelet részben alkalmaznak, és szinte minden szervezet szervez tagjainak és külső partnereinek rendezvényeket, amelyeken keresztül megismerhetik a szervezet tevékenységét.

\section{A Felvidék magyarlakta területén javasolható TDM szervezeti- és együttmúködési formák}

A következókben bemutatjuk a vizsgált térségben javasolható TDM szervezeti formákat, és azonosítjuk a tevékenységek hatékonyságát növeló múködési és szakmai feladatokat.

\subsection{A FELVIDÉK MAGYARLAKTA TERÜLETÉN KIALAKÍTANDÓ TDM SZERVEZETEK LEHETSÉGES TÍPUSAI ÉS EGYÜTTMŰKÖDÉSI FORMÁI}

Az elsó, és az általunk is leginkább támogatott, alternatíva szerint a Felvidéken egy ernyószervezet és több térségi TDM szervezet szükséges e tevékenység ellátására. A vélemények egyik része szerint egy szervezet önmagában nem lenne képes az egész Felvidék magyarlakta területén a turisztikai feladatok ellátására, mert a térség eltérő karakterrel és táji sajátosságokkal rendelkezik, és a kelet-nyugati térségek nagy távolságra vannak egymástól.

Az azonban, hogy még nem létezik ilyen ernyőszervezet, nem jelenti azt, hogy ennek a folyamatnak a megfordítása ne lenne stratégiai fontosságú célkitúzés. A Felvidék magyarlakta területei turisztikai versenyképességének növelése érdekében szükség lenne egy ernyőszervezetre (Felvidéki Turisztikai Ügynökségre/Egyesületre/Szövetségre), amelynek székhelye Pozsonyban lehetne, és amely összefogná és tanácsadással segítené a területi szintú szervezeteket, a magyarlakta területek turizmusát. A szervezet feladatköre fóként a szakmai segítségnyújtásra, a koordináló, tanácsadó és képzési tevékenységekre terjedne $k i$, illetve érdemes lenne a Felvidék magyarlakta területét 'külön csomagként' értékesítenie.

$\mathrm{Az}$ ernyőszervezet mellett egybetartozó tájegységek tudnának TDM szervezeteket alkotni, és szükséges, hogy egységes területi szinten, a hagyományos együttmúködések mentén kerüljenek lehatárolásra, azaz térségi szintû, alulról jövố szerveződé- sekre van szükség. Minden térséget külön csomagként lehet ajánlani, ezért szervezeti szinten is ezekre a területekre érdemes építeni. Megyei szinten nincs erôs együttmúködés, inkább a területi szervezetek múködnek jól. Ezek szerint összesen három, vagy négy kelet-, közép-és nyugat térségi TDM szervezetet célravezetó megalakítani, amelyek a magyarlakta területek turizmusát irányítanák, a magyarság öszszefogását erôsítenék, és amelyek be tudják vonni a már múködő szervezeteket is. Az alábbi térségekben javasolhatók térségi TDM szervezetek:

- Rimaszombat és térsége,

- Kassa vidéke és Bódva völgye,

- Csallóköz,

- Ipoly és Garam mente,

- Gyúgy és térsége (amely részben az Ipoly vidéke),

- Ung vidék és Bodrogköz,

- Nógrád térsége (Fülek központtal),

- Duna mente,

- Párkány és térsége.

A másik alternatíva szerint a határon átnyúló kapcsolatokra épithetók fel TDM szervezetek, illetve a regionális fejlesztési ügynökségek keretében is múködhetnének TDM típusú szervezetek. Ezek szerint is alulról építkező szervezetekre van szükség, és ebben a formában jól múködnek a határon átnyúló kapcsolatok. Ezáltal akár határon átnyúló szervezet is elképzelhetó a Felvidék magyarlakta területei turizmusának irányítására. A határon átnyúló TDM típusú feladatok ellátása megvalósítható lehet a regionális fejlesztési ügynökségek, illetve az EGTC-k keretében. A szakemberek ennek lehetôségét azzal indokolják, hogy sok megalakuló szervezet van, amelyek nem kapcsolódnak egymáshoz, ezáltal nincsen akkora erejük, nincs kiépített szervezeti struktúrájuk, így gyorsan elhalnak. Az állam nem fogja már támogatni az új szervezeteket, hiszen ezek az ország egész területét lefedték, így fóként a meglévó szervezeteket szükséges megerôsiteni turisztikai funkciókkal, és a már meglévő szervezetek múködését kellene racionalizálni, szervezeti rendszerbe állítani, pénzügyi szempontból is fenntarthatóvá tenni.

A harmadik alternatíva szerint a Csemadok (Szlovákiai Magyar és Társadalmi és Közmüvelődési Szövetség) keretében is müködhetnének TDM típusú szervezetek. Ehhez azonban közös turisztikai és kulturális célokra, tervekre, stratégiára, illetve közös érdekeltségi- és ellenőrzési/értékelési rendszer kidolgozására van szükség. Ebben az esetben is javasolható a térségi szintú szerveződés, amivel ugyancsak legalább négy szervezetet lehetne kialakítani, egy keletit, egy közép-szlovákiait és két nyugatit. 
A negyedik alternatíva szerint térségi TDM szervezetek kialakítása indokolt, és a jelenleg geopark státuszban lévó Novohrad-Nógrád Geopark alkalmas lenne térségi TDM szervezetként való múködésre. E szerint a geopark alkalmas lenne a TDM feladatok ellátására, a lehetőség megvan bennük, a települések összefogása megkezdődött, csak szakértők és források bevonására lenne szükség. A szervezet 40 km-es körzetben rendelkezik tagsággal. Jelenleg 28 tagja van, és még további 11 új tag belépése várható.

\subsection{JAVASLATOK A FELVIDÉK MAGYARLAKTA TERÜLETÉN KIALAKÍTANDÓ TDM SZERVEZETEK MÜKÖDÉSÉRE ÉS SZAKMAI TEVÉKENYSÉGÉRE}

A szervezetek kiszámítható múködéséhez 3-5 éves költségvetési programozásra lenne szükség, valamint támogatásra a jó múködéshez. A több szervezet által is említett múködési, pénzügyi kiszámíthatatlanság és bizonytalanság megszüntetése meghatározó lenne a szervezetek fenntartható múködéséhez. A Pozsony megye által a közeljövőben kialakítandó nemzetiségi alap segítséget fog jelenteni a Pozsonyban tevékenykedő szervezetek számára, illetve a szlovák kormány továbbra is lehetőséget nyújt a TDM szervezetek finanszírozására. A magyarországi pályázati lehetôségeket nem ismerik, nem látják, azonban szükség lenne további múködési támogatásra, több irányú finanszírozási támogatásra. Egy másik véleményben megjelenik, hogy a kiszámíthatatlan finanszírozási háttéren segítenének a magyarországi források, amely támogatná a magyarlakta vidékeket. Érdekvédelemre és anyagi támogatásra van szükség. A turisztikai bevételek növelésére, a kiegészítő jövedelmek biztosítására, a szervezet önfenntartóvá válására adna további lehetőséget az üzleti és kereskedelmi célú tevékenység.

A szakmai tevékenységen belüli megalapozó kutatási tevékenység és a piackutatások lehetóséget adnának a fóbb turisztikai trendek vizsgálatára, a piaci felmérésekre, a kereslet-kínálati elemzés megvalósítására. A keresleti szegmensek azonosítása orientálhatja a turisztikai termékek fejlesztését. A piackutatásokhoz statisztikai adatgyúités és rendszerezés szükséges.

A termékfejlesztés terén a természeti és a kulturális erőforrások feltárása és hasznosítása, a gasztronómiai turizmus, a borturizmus, a helyi termékekkel kapcsolatos fejlesztések, a vonzerók látogatóbarát fejlesztése, a vonzerôk és környezetük infrastrukturális fejlesztése, a célcsoport specifikus turisztikai programcsomagok és mintaprogramok kialakításának és kommunikálásának szükségessége, valamint a szolgáltatások minősé- gének fejlesztése azonosítható. Az elszigetelt és pontszerú fejlesztések helyett komplex, nagyobb térséget átfogó fejlesztésekre van szükség.

Látható, hogy a Felvidék magyarlakta területe iránt kisebb az érdeklődés, mint Szlovákia északi területei iránt. Ez felhívhatja a turisztikai szakemberek figyelmét arra, hogy a térségről erôteljesebb üzeneteket és információkat kell közvetíteni a küldő piacok irányába.

A Felvidék magyarlakta területein a TDM szervezetekkel már rendelkező, és a jövőben TDM szervezeteket kiépító térségekben is szükséges kialakítani a megfeleló ismertséget felmutatni képes turisztikai márkanevet és márkatermékeket. A térség sikeres marketingkommunikációjának további feltétele a világos, egyértelmú, vendégkör-orientált pozicionálás. Ehhez vizsgálni szükséges az ideérkezó turisták fogyasztói szokásait, tudni kell, miért jönnek ide a vendégek, milyen fogyasztói igényeik vannak, mit kell erósíteni és bemutatni a marketingkommunikációban.

A szervezeteken belül és között is intenzív együttmúködés szükséges. A fentiekkel összefüggésben mind a tagok, mind a szervezetek között szükséges a szakmai fórumok, kerekasztal beszélgetések, tudásátadás, interaktív kommunikáció, állandó szakmai továbbképzések, e-learning tanfolyamok szervezése, motivációs rendszer kiépítése, tapasztalatszerzés más és hasonló szervezeteknél, közös adatbázisok kialakítása (például termelői, civil katalógus), amelyek segítséget jelenthetnek a partneri kapcsolatok kialakításában.

Nagyobb felelôsségtudat kialakítására lenne szükség a helyi értékek felismerése, megőrzése és hasznosítása terén. Ehhez több magyar ajkú turisztikai szakemberre lenne szükség.

\section{5. Összefoglalás}

A legtöbb válaszadó szerint a Felvidék magyarlakta területeinek turizmusa közepesen versenyképes Szlovákia más turisztikai térségeihez képest. Több vélemény is megerősíti, hogy e térség gazdag turisztikai kínálattal rendelkezik, azonban a lehetőségek nincsenek megfelelően kihasználva. A térség bóvelkedik turisztikai erőforrásokban, mint például gasztronómia, gyógy- és termálvizek, borok, természeti értékek, a vízi turizmus feltételei és az itt élők kedvessége, vendégszeretete. A turisták számára vonzó a magyar történelem, a hagyományok, a kultúra.

A magyarlakta területek turisztikai statisztikai adataiból kitúnik, hogy egyelőre nem tud versenyelónyre szert tenni a természeti és kulturális értékekben gazdagabb, többségében szlovákok lakta területekhez, így például a Magas-Tátrához, 
Poprádhoz, Besztercebányához, Trencsénteplichez képest. A vendégek és a vendégéjszakák száma tekintetében a magyarlakta kerületek Szlovákia vendégforgalmában a középső és az utolsó mezônyben helyezkednek el, Pozsony kivételével, amely vezetó szerepet tölt be a magyarlakta területek (és Szlovákia) vendégforgalmában.

A dél-szlovákiai területeken a vonzerôk elszigetelten vannak jelen, ami helyett komplex, nagyobb térséget átfogó fejlesztésekre, a jelenleg még hiányzó célcsoport specifikus turisztikai programcsomagok kialakítására, a vonzerők élményszerú fejlesztésére, a vonzerók környezetében infrastruktúrafejlesztésre és a turisztikai szolgáltatások számának és minóségének javítására lenne szükség. A válaszokban megjelenik, hogy a turisták kedvelik e térség kínálatát, ugyanakkor szélesebb körben szükséges kommunikálni, amivel még nagyobb keresletet lehetne iránta generálni.

A forrásszerző képesség is viszonylag gyenge, másrészt kevés pályázati ötlet realizálódik, amely a Felvidék magyarlakta területének viszonylagos elzártságából ered.

A felvidéki szervezetek vizsgálatában látható, hogy a jó példák jelen vannak az együttmúködésre, az összefogásra. A szervezetek többsége kiterjedt kapcsolatokkal rendelkezik, sok projektet és rendezvényt valósít meg. Több jó kezdeményezést is láthatunk a szervezetek között, akik sokat tesznek a magyarság értékeinek ápolása és átörökítése terén. Viszont vannak olyan vélemények is, melyek szerint hiányzik a magyarság összefogása és együttes cselekvése, a közös gondolkodás, a nyitottság a másik felé.

Az interjúban részt vett szervezetek a saját tevékenységükkel kapcsolatban kiemelik a sikeres tevékenységet, a belsô- és külső tagok közötti jó együttmúködést, a nehézségek ellenére történó fennmaradást, a nyitottságot, a mindig változó körülményekhez történó alkalmazkodást. Mások a sikeres, eredményes tevékenységet, és a jelentős szakmai potenciálokat emelik ki, azonban hiányolják a kiszámítható finanszírozási hátteret és ezáltal az elegendô munkatársi létszámot, a stratégia meglétét és az együttes cselekvést.

A szakmai interjúkból és a statisztikai elemzésekből is körvonalazódik, hogy erôsebb érdekképviseleti képességgel rendelkezó és hatékony szakmai tevékenységet végző szervezetek kialakításával, erôteljesebb marketing tevékenységgel még eredményesebbé válna a térség turizmusa. Kutatásunkban javaslatot tettünk arra, hogy a térség e célt egy felvidéki ernyőszervezet és több térségi TDM szervezet együttes tevékenységével tudná elérni.

\section{Felhasznált irodalom}

A TURIZMUS TÁMOGATÁSÁRÓL SZÓLÓ SZLOVÁK TÖRVÉNY (91/2010. számú).

BAROSS GÁBOR TERV (2014): Dél-Szlovákia/ Felvidék regionális gazdasági fejlesztési terve. Szlovákiai magyar közgazdász társaság, Dunaszerdahely.

BUHALIS, D. (2000): Marketing the competitive destination in the future. Tourism Management. 21(1). pp. 97-116.

CSIFFÁRY T. (2007): Felvidék gyöngyszemei. Titán Computer Kft., Budapest.

CSONKA Á. (2014): A Felvidéki Legendárium megvalósitásának lehetôségei. Készült a TÁMOP7.2.1-11/K-2014-0001 "Az Emberi Eróforrás Fejlesztési Operatív Program tervezésének és szakmai-módszertani megalapozásának támogatása" keretében. pp. 1-38.

FELVIDEKI MAGYAROK (2012): elektronikus folyóirat. 2012/III. Készítette: Szövetség a Közös Célokért Társulás. http://felvidek. $\mathrm{ma} / \mathrm{wp}$-content/uploads/2012/02/fm5.pdf

GÁSPÁR K. - SÁRA B.- SIMON A. (2005): A Felvidék száz csodája. Totem Plusz Kiadó, Budapest.

HORVÁTH GY. (szerk.) (2004): A Kárpátmedence régiói 2. Dél-Szlovákia. A Magyar Tudományos Akadémia Regionális Kutatások Központja és Dialóg Campus Kiadó, Budapest-Pécs.

KÓSA P. (szerk.) (2014): A Kárpát-medence örökségturisztikai atlasza. 1. kötet: Épitett örökség. Talma Kiadó, Pécs.

LENGYEL M. (szerk.) (2008): TDM Múködési Kézikönyv. Heller Farkas Fóiskola, Budapest.

NAGY B. (szerk.) (2015): A Felvidék legszebb túraútvonalai. I.P.C. Könyvek Kft., Budapest.

NEMZETI TURIZMUSFEJLESZTÉSI STRATÉGIA 2005-2013 (2005). Készítette: Magyar Turisztikai Hivatal, Budapest.

SZOBONYA G. (2014): A felvidéki örökség turisztikai jelentôsége. Szakdolgozat. DebreceniEgyetem Gazdálkodástudományi és Vidékfejlesztési Kar Vidékfejlesztési és Funkcionális Gazdálkodási Intézet, Debrecen.

VIDA P. (2016): A Felvidék kulturális és természeti értékei. TKK Kereskedelmi Kft., Debrecen.

\section{Internetes forrás}

Szlovák Statisztikai Hivatal (2001-2015): https://slovak.statistics.sk, Letöltve: 2017. január 7. 